\title{
Parenteral administration of L-arginine to twin-bearing Romney ewes during late pregnancy is associated with reduced milk somatic cell count during early lactation
}

\author{
Quentin L. Sciascia, ${ }^{1,2 *}$ Danitsja S. van der Linden, ${ }^{1,2} \dagger$ Francisco A. Sales,,${ }^{1,2} \ddagger$ Nina J. Wards, ${ }^{1}$ Hugh T. Blair, ${ }^{2,4}$ \\ David Pacheco, ${ }^{1}$ Mark H. Oliver, ${ }^{2,3}$ and Susan A. McCoard ${ }^{1,2} \S$ \\ ${ }^{1}$ AgResearch Grasslands, Palmerston North 4442, New Zealand \\ ${ }^{2}$ Gravida, National Centre for Growth and Development, University of Auckland, Auckland 1023, New Zealand \\ ${ }^{3}$ Ngapouri Research Farm, Liggins Institute, University of Auckland, Auckland 3083, New Zealand \\ ${ }^{4}$ International Sheep Research Centre, Massey University, Palmerston North 4442, New Zealand
}

\section{ABSTRACT}

Maternal milk is the primary source of nutrition for suckling mammals, and its yield and composition are important determinants of survival during the early neonatal period. The objective of this study was to examine whether parenteral administration of L-Arg to twin-bearing ewes, during mid to late pregnancy, influenced prepartum maternal mammary gland development and subsequent lactation performance in the early postpartum period (14 d). At $80 \mathrm{~d}$ of pregnancy, multiparous Romney ewes were housed indoors in group pens, split into 2 cohorts, and fed a lucerne-based pellet diet, formulated to meet $100 \%$ of National Research Council-recommended requirements for twin-bearing pregnant ewes, once a day. Cohort 1 was administered L-Arg $(72.7 \mathrm{mg} / \mathrm{kg}$ of live weight via i.v, 3 times a day) from d 100 of pregnancy until d 140. At d 140, ewes were euthanized and maternal mammary tissues were collected for analysis of the biochemical indices total DNA, RNA, protein, protein synthetic efficiency (protein:RNA), cell size (protein:DNA), transcriptional efficiency (RNA:DNA), and the abundance of mammalian target of rapamycin (mTOR) and $\mathrm{mTOR}^{\mathrm{Ser} 2448}$ protein. Cohort 2 was administered an identical L-Arg regimen as cohort 1 , but from d 100 until parturition. Milk was collected over a 14-d period (d 1, 4, 7, 10, and 14) to assess milk yield and composition. In cohort 1 ,

Received July 24, 2018.

Accepted November 30, 2018

*Current address: Leibniz Institute for Farm Animal Biology, Institute for Nutritional Physiology (Oskar Kellner), Dummerstorf, Germany.

†Current address: Focus Genetics Ltd., Napier, New Zealand.

$\ddagger$ Current address: Instituto de Investigaciones Agropecuarias,

Department of Animal Production Science, Punta Arenas, Chile.

$\S$ Corresponding author: sue.mccoard@agresearch.co.nz total mammary DNA (cell number) tended to be higher in L-Arg ewes, with no change in total mammary RNA or protein content, biochemical indices of protein synthetic efficiency, cell size or transcriptional efficiency, or mTOR protein abundance or phosphorylation. In cohort 2, milk composition analysis from L-Arg ewes showed lower (d 7-14) milk somatic cell counts, greater crude protein percentage from d 7 to 10 but lower at d 14, and altered absolute concentrations of some free AA (d 7 and 14) compared with controls. We propose that parenteral administration of L-Arg during late pregnancy is associated with increased mammary gland cellular content and decreased somatic cell counts during early lactation.

Key words: sheep, dairy, L-arginine, somatic cell, milk composition

\section{INTRODUCTION}

A critical development phase of the ruminant mammary gland is during pregnancy (Anderson, 1975), when the size of the mammary gland precipitously (Robinson et al., 2009) increases to support an elevation in the number, size, and milk production potential of secretory cells (Anderson, 1975). At parturition, the number of secretory cells in the mammary gland does not increase, whereas secretory cell milk production potential remains plastic (Akers et al., 1981). Thus, pregnancy provides an opportune time to develop intervention strategies aimed at increasing subsequent lactation performance. Supplementation with specific nutrients, in particular AA, may enable the stimulation of mammary gland development and function (Kim and $\mathrm{Wu}, 2009$ ). Of particular interest is L-Arg, which is essential for mammary gland development in pregnant rats (Pau and Milner, 1982) and increases milk yield when supplemented during late-pregnancy in Holstein cows (Chew et al., 1984). 
L-Arginine is used by the mammary gland to synthesize polyamines and nitric oxide (NO; Clark et al., 1975; Mepham, 1982). Polyamine synthesis supports a large number of cellular processes within the mammary gland, such as DNA stabilization (Ploszaj et al., 2000), cell growth, proliferation, differentiation, and the regulation of casein synthesis (Rillema et al., 1977). LProline and L-glutamate production supports increased lactation, as L-Pro is not taken up in sufficient quantities by the lactating gland to support casein synthesis (Basch et al., 1997), whereas L-glutamate is used as an energy source and in the production of L-Gln, the most abundant AA in milk protein (Davis et al., 1994). Nitric oxide is produced by nitric oxide synthase (NOS), an enzyme that is activated by prolactin and converts L-Arg to NO and L-Cit (Bolander, 1999). Mammary gland intracellular NO has been shown to aid prolactin receptor release from internal compartments so that it can move to the cell surface and elevate prolactin signaling (Bolander, 1999). Nitric oxide also provides support for the immune system (Boulanger et al., 2001) in response to IMI.

A pathway activated in response to L-Arg supplementation (Yao et al., 2008; Kim et al., 2011) and LGln (Nicklin et al., 2009) is the mammalian target of rapamycin (mTOR). At the core of the pathway is the mTOR protein, an evolutionarily conserved serine threonine kinase that exists in 2 known complexes, mTORC1 and mTORC2 (Laplante and Sabatini, 2012). In all mammalian species, both complexes regulate cell growth, proliferation, differentiation, and protein synthesis, with mTORC1 serving a more dominant role (Alessi et al., 2009; Laplante and Sabatini, 2012). In vitro and in vivo studies of mammary gland development and function show that Ile and Leu supplementation (Appuhamy et al., 2012), growth hormone (Sciascia et al., 2013), and lactogenic hormones (Sobolewska et al., 2009) stimulate the abundance and activation of factors belonging to the mTOR pathway. The purpose of our study was to determine if L-Arg administration during late pregnancy in twin-bearing Romney ewes influences maternal mammary gland development, lactation performance and mTOR abundance in the early postpartum period.

\section{MATERIALS AND METHODS}

\section{Animals and Treatments}

This study was conducted at the Ngapouri Research Farm, $30 \mathrm{~km}$ south of Rotorua, New Zealand. All procedures involving animals were carried out in compliance with the guidelines of the University of
Auckland Animal Ethics Committee (Auckland, New Zealand; Permit number C889), in accordance with the 1999 Animal Welfare Act of New Zealand. Multiparous Romney ewes, sourced from the same commercial supplier (Landcorp Farming Ltd., Mangamingi Station, Wellington, New Zealand) were synchronized and naturally mated to 1 of 2 Poll Dorset sires (McCoard et al., 2013). At mating, ewe live weight was 65 to $75 \mathrm{~kg}$ with a BCS of 3 to 3.5 (1 to 5 scale). Ewes were managed under New Zealand pastoral grazing conditions to meet or exceed nutritional requirements. At d 60 postmating, transabdominal ultrasonography was used to identify twin-bearing ewes. All twin-bearing ewes were transferred back to pasture and, 2-wk before indoor housing, were fed a lucerne-based pellet diet (University B mix, Camtech Nutrition, Cambridge, New Zealand), which provided up to $20 \%$ of daily requirements. All non-twin bearing ewes were returned to the main flock.

At d 80 of pregnancy, ewes were placed in group pens and acclimatized to indoor housing and a lucernebased pellet-only diet (Table 1; previously published in McCoard et al., 2013), formulated to meet $100 \%$ of NRC-recommended requirements for twin-bearing pregnant ewes (NRC, 1985) with water freely available. The formulation is also compliant with other reputable and practical guides on feeding pregnant ewes during experimentation. Ewes were fed once daily (between 0800 and $0900 \mathrm{~h}$ ) and, on d 90, moved to individual pens with mesh sides to facilitate visualization with other animals. Ewe weight and BCS (scale of 1 to 5) were recorded weekly, feed allowance was adjusted according to live weight changes (NRC, 1985), and daily feed intake was recorded as the difference between fed offered and refused, on a DM basis, as reported in our previous study (McCoard et al., 2013).

\begin{tabular}{lc}
$\begin{array}{l}\text { Table } 1 . \text { Composition of the lucerne-based diet fed to the ewes during } \\
\text { the duration of the trial }\end{array}$ \\
\hline Item & Content \\
\hline ME (MJ/kg of DM) & 10.04 \\
DM (\%) & 86.9 \\
Composition (\% of DM) & \\
CP & 17.1 \\
Lipid & 2.9 \\
Ash & 3.9 \\
ADF & 20.9 \\
NDF & 41.9 \\
Soluble sugars and starch & 11.7 \\
Macroelement composition $(\%$ of DM) & \\
Potassium & 2.01 \\
Magnesium & 0.29 \\
Phosphorus & 0.38 \\
Calcium & 1.25 \\
Sulfur & 0.33 \\
Sodium & 0.40 \\
\hline
\end{tabular}


At d 95 of pregnancy, ewes were randomly assigned to either L-Arg or control (saline administration) groups (McCoard et al., 2013). At d 97, polyvinyl catheters were inserted into the tarsal vein of the hind leg under brief anesthesia induced by injectable anesthetic and sedation (combination of $0.5 \mathrm{mg} / \mathrm{kg}$ of $\mathrm{BW}$ diazepam and $10 \mathrm{mg} / \mathrm{kg}$ of $\mathrm{BW}$ ketamine, Parnell Technologies, Auckland, New Zealand). The externalized catheter was flushed with heparinized saline $(0.9 \%$ sodium chloride, Baxters Healthcare Pty Ltd., Old Toongabbie, Australia; $10 \mathrm{U} / \mathrm{mL}$ of sodium heparin), sealed with stopcocks, secured in a plastic bag, and anchored to the mid-line of the ewe. The bag and catheter were further secured with tube netting. After catheter insertion, the ewes received 1 dose of prophylactic i.m. antibiotics (Duplocillin LA, Intervet Ltd., Newmarket, Auckland, New Zealand, $2 \mathrm{~mL} / 50$ $\mathrm{kg}$ of live weight). Ewes, from d 100 to 140 of gestation (cohort 1), or from d 100 to parturition (cohort 2 ), received an intravenous bolus of either L-argininemono-hydrochloride (L-arginine-HCL; Merck KGaA, Darmstadt, Germany; $72.7 \mathrm{mg} / \mathrm{kg}$ of live weight) or approximately the same volume of sterile saline 3 times daily $(0800,1600$, and $2400 \mathrm{~h}$ ). The Arg dosage was based on a study conducted by Lassala et al. (2011), who reported it increased maternal plasma Arg concentrations. Preparation of the Arg solution and catheter cleaning has been reported in a previous study (McCoard et al., 2013). Briefly, a fresh Arg solution was prepared daily using sterile physiological saline $(0.9 \%$ sodium chloride, Baxter Healthcare Pty Ltd.) to a final concentration of $1.8 \mathrm{~g}$ of $\mathrm{Arg} / 5 \mathrm{~mL}$ and $\mathrm{pH}$ adjusted to 7.0 with $1 \mathrm{~mol} / \mathrm{L}$ of $\mathrm{NaOH}$.

Cohort 1. At d 140, ewes were euthanized (0.5 $\mathrm{mL} / \mathrm{kg}$ of BW of Pentobarb 300, Provet NZ Pty Ltd., Auckland, New Zealand). Following euthanasia, mammary glands had the skin and teats removed and were trimmed of excess connective tissue and weighed. Tissue samples were then collected from the middle of the left side udder parenchymal tissue, to avoid large blood vessels and connective tissue, and snap frozen in liquid nitrogen $\left(-80^{\circ} \mathrm{C}\right)$ within 5 min for subsequent analysis of biochemical indices and mTOR pathway activation. From the 23 ewes available in the d-140 gestation group, 3 were omitted from the study; 1 ewe had a defective catheter and 2 ewes aborted their lambs before d 140 of pregnancy. In total 20 ewes were used (arginine group $\mathrm{n}=9$; control group $\mathrm{n}=11$ ).

Cohort 2. At the first sign of initiation of labor, which was between 1 and $10 \mathrm{~h}$ before birth, L-Arg administration ceased. One ewe was omitted from the study due to aborting her lambs. In total, 25 ewes were used (arginine group, $\mathrm{n}=13$; control group $\mathrm{n}=12$ ).
Ewes were assigned to milking groups based on parturition date. The animals in this cohort were part of a wider study (McCoard et al., 2013), and a colostrum sample collected within $12 \mathrm{~h}$ postpartum could have compromised animal behavior and ewe-lamb bond formation. Therefore, the first milk sample, labeled colostrum, was collected between 13.9 and $36.6 \mathrm{~h}$ after the birth of the first lamb. The ewes were milked following an intravenous injection of $1 \mathrm{IU}$ of synthetic oxytocin (Oxytocin V, $10 \mathrm{IU} / \mathrm{mL}$, PhoenixPharm, Auckland, New Zealand; van der Linden et al., 2009) and milked by machine and hand-stripped to remove any residual milk from the gland. The time when the udder was empty was recorded. Animals were milked again (machine and hand-stripping) approximately 4 $\mathrm{h}$ later, with the time and weight of the milk recorded. Daily yields of milk, protein, lactose, and fat were then calculated using the following formula (van der Linden et al., 2009):

(24 h/time between milkings) $\times$ milk yield at subsequent milking.

Lambs were separated from the ewes during the intervening 4 -h period and bottle fed as required using the milk collected from their respective dams. Throughout milking dams and offspring were housed in individual pens immediately adjacent to each other. The same operators milked all ewes throughout our study using a mobile milking machine (DeLaval, Hamilton, New Zealand). Dams were milked in the morning between 0830 and $1230 \mathrm{~h}$ on $\mathrm{d} 4,7,10$, and 14 of lactation. To account for variations in the exact time and day of milking, as well as the potential effect on composition and yield, the following formula was used to create the covariate days in lactation:

\section{[(Date and time of milking - date and time} of previous milking) $/ 24 \mathrm{~h}$ ] = days in lactation.

Milk obtained after the 4-h intervening period was subsampled for analysis of milk composition (percent fat, $\mathrm{CP}$, and lactose and SCC). Milk samples were preserved with bronopol and refrigerated at $4{ }^{\circ} \mathrm{C}$ until analysis using a FT120-FTIR, calibrated for sheep milk (DairyNZ, Hamilton, New Zealand). Two reference checks (fat and $\mathrm{CP}$ ) were taken once a week (colostrum, $\mathrm{d} 7$ and 14) to account for changes in the matrix of the milk. Somatic cell counts were determined using a bromide-based fluorescent dye and a FOSS flow Cytometer (MilkTestNZ, Hamilton, New Zealand). 


\section{Biochemical Indices (Cohort 1)}

Total RNA, DNA, and protein were extracted, purified, and quantified as previously described (Sciascia et al., 2013). Briefly, mammary tissue from each ewe was homogenized in TRIzol reagent (Life Technologies, Auckland, New Zealand), and total RNA, DNA, and protein were extracted according to the manufacturer's protocol. Nucleic acids were quantified using a NanoDrop spectrophotometer (ND-1000; Nanodrop Technologies, Wilmington, DE) and protein was quantified using the Quant-iT Protein Assay Kit and Qubit 1.0 fluorometer (Life Technologies).

\section{Immunoblotting (Cohort 1)}

Protein samples extracted for biochemical indices analysis were prepared at concentrations of $10 \mu \mathrm{g} / \mu \mathrm{L}$ in $4 \times$ NuPAGE LDS Sample Buffer (Life Technologies) as per the manufacturer's instructions. Aliquots of protein $(80 \mu \mathrm{g})$ were electrophoretically separated via reducing SDS-PAGE using 3 to $8 \%$ premade Tris-acetate gels (Life Technologies) according to the manufacturer's instructions. The remaining binding sites on the blots were blocked for $1 \mathrm{~h}$ at room temperature using $5 \%$ skim milk suspended in Tris buffered saline (TBS) that included $0.1 \%$ Triton-X. Proteins were then transferred to a polyvinylidene difluoride membrane using an iBlot 1 Gel Transfer Device (Life Technologies) set to transfer program $3(20 \mathrm{~V}$ for 6 $\mathrm{min})$. The polyvinylidene difluoride membranes were then incubated overnight at $4^{\circ} \mathrm{C}$ with rabbit polyclonal primary antibody $\mathrm{mTOR}^{\mathrm{Ser} 2448}$ (Cat No: 2971; Cell Signaling Technologies, Boston, MA) prepared at 1:500 using $1 \times$ TBS. Blots were subsequently washed 3 times (5 min each) with TBS with Triton-X, and incubated 1 $\mathrm{h}$ with 1:5,000 horseradish peroxidase-conjugated goat anti-rabbit secondary antibody (Cat No. 7074S; Cell Signaling Technologies) prepared in blocking buffer. Proteins were then visualized using SuperSignal West Pico enhanced chemiluminescence reagents (BioRad, Auckland, New Zealand), Kodak Biomax XAR film (Rochester, NY), and an All Pro 100 plus automatic film developer (Radiographic Supplies, Auckland, New Zealand). Three repeat films were scanned using an HP Photosmart B110 scanner (Hewlett Packard, Auckland, New Zealand), and the peak area of individual bands determined by using the image analysis software ImageJ (National Institutes of Health, Bethesda, MD). Blots were then stripped using ROTI-free stripping buffer (Carl Roth, Karlsruhe, Germany) according to the manufacturers' protocol and reprobed with a rabbit polyclonal antibody used to detect the total form of mTOR (Cat No. 2972; Cell Signaling) at a 1:5,000 dilution in TBS.

\section{Free AA Profile in Milk (Cohort 2)}

Free amino acid (FAA) profiles in milk were analyzed using HPLC as previously described (Sciascia et al., 2015). Skim milk $(500 \mu \mathrm{L})$ was mixed with $500 \mu \mathrm{L}$ of lithium extraction buffer (14 g/L of lithium chloride, $3 \mathrm{~g} / \mathrm{L}$ of lithium hydroxide, $1 \mathrm{~g} / \mathrm{L}$ of phenol, $50 \mathrm{~g} / \mathrm{L}$ of sulfosalicylic acid) and placed on ice for 15 to $20 \mathrm{~min}$. Volumes of $10 \mu \mathrm{L}$ of lithium hydroxide $(5.88 \mathrm{M})$ were added to the sample to obtain a final $\mathrm{pH}$ of 1.5 to 2 . This was followed by centrifugation at $13,680 \times g$ for $5 \mathrm{~min}$ at $4^{\circ} \mathrm{C}$ and filtering the resulting supernatant through a $4-\mathrm{mm}, 0.2-\mu \mathrm{m}$ syringe filter. The filtered sample was analyzed for FAA using a Shimadzu LC10Ai HPLC (Shimadzu Oceania Ltd., Auckland, New Zealand), fitted with a high-efficiency lithium-ion exchange column (3 mm i.d. × 150 mm; Shimadzu Oceania Ltd.). Injected volumes were $10 \mu \mathrm{L}$, the reagent flow rate was $0.3 \mathrm{~mL} / \mathrm{min}$, and the run was $162 \mathrm{~min}$ between injections using lithium buffers as eluents and ninhydrin postcolumn derivatization.

\section{Statistical Analyses and Calculations}

Biochemical Indices. The concentrations of DNA, RNA, and protein were adjusted by the weight of the tissue used for nucleic acid and protein isolation to generate mammary tissue values. The mammary tissue values (per milligram) were then used to assess potential biochemical indices changes. The index of cell size or hypertrophy was assessed by dividing the protein value by the DNA value. The DNA value is a measure of cell number per milligram of tissue; as the protein value per unit of DNA (cell) increases, so does cell size or hypertrophy (Nader et al., 2005). The index of transcriptional efficiency or cellular RNA content was performed in a manner identical to that of cell size or hypertrophy, but dividing the RNA value by the DNA value (Nader et al., 2005). The index of protein synthetic efficiency was assessed by dividing the protein value by the RNA value. The RNA value is a biochemical index of the translational capacity of the mammary tissue, as the majority of the cellular RNA pool consists of ribosomal RNA. When the protein value per unit of RNA increases, this indicates increased protein synthetic efficiency. Total parenchymal DNA, RNA, and protein were calculated by multiplying mammary tissue nucleic acid and protein values by the weight of the mammary gland. Biochemical indices and total 
parenchymal DNA, RNA, and protein content between administration groups were determined using the MIXED procedure in SAS version 9.3 (SAS Institute Inc., Cary, NC), which included the fixed effect of dam administration group. From the 20 ewes available, only 18 were used for statistical analysis (arginine group $\mathrm{n}$ $=8$; control group $\mathrm{n}=10)$. Two ewes $(1$ arginine and 1 control) were removed after boxplot analysis showed mammary gland weight for these 2 animals were outliers. Probability values $\leq 0.05$ were considered statistically significant, whereas trends were declared when $0.05<P \leq 0.15$.

Western Blotting. For each Western blot, the area of each peak obtained was calculated per microgram of DNA. These values were then expressed as a percentage of the total area from all bands on the film to reduce variation between repeat films (abundance of total and phosphorylated protein). Differences between administration groups were analyzed using the MIXED procedure (SAS Institute Inc.) that included the fixed effect of dam administration group and reported as a normalized peak area per microgram of DNA. Probability values $\leq 0.05$ were considered statistically significant, whereas trends were declared when $0.05<P$ $\leq 0.15$.

Milk and Composition Yields. Repeated measures analysis of milk yield and composition using the MIXED procedure (SAS Institute Inc.) with a linear model that included the fixed effects of dam, dam administration group, and the covariates average dam live weight, average dam BCS, and days in lactation in the model. From the 25 ewes available only 18 were used for statistical analysis (arginine group $\mathrm{n}=8$; control group $\mathrm{n}=10$ ). One ewe had an infected udder and was removed from the trial after $d 1$, whereas 6 ewes had blind teats that significantly affected milk yield. Probability values $\leq 0.05$ were considered statistically significant, whereas trends were declared when $0.05<$ $P \leq 0.15$.

Milk FAA Profiles. Differences for individual AA, total AA, and the sums of EAA, NEAA, branchedchain AA, arginine-family AA (Arg, aspartate, Asn, glutamate, Gln, Pro, Orn), and groups of AA defined by their mammary metabolism as outlined by Mepham (1982) - group I (Met, Phe, Tyr) and group II (Arg, His, Ile, Leu, Lys, Val) — were assessed using the MIXED procedure (SAS) with a linear model that included the fixed effects of dam, dam administration group, and the covariates average dam live weight, average dam BCS, and days in lactation. Free AA values are reported as micromoles per liter of milk. Probability values $\leq 0.05$ were considered statistically significant, whereas trends were declared when $0.05<P \leq 0.15$.

\section{RESULTS}

\section{Effect of L-Arg on Mammary Gland Weight, Biochemical Indices, and mTOR Pathway Activation (Cohort 1)}

Total mammary DNA tended to be greater $(P=$ 0.07 ) in ewes administered L-Arg compared with controls (Table 2). No differences were observed in any of the other biochemical indices measures or mammary gland weight (Table 2). The abundance of total, Ser2448 phosphorylated, or relative mTOR protein activation was unaffected by L-Arg administration in the mammary glands of ewes at d 140 (Figure 1).

\section{Effect of L-Arg on Milk Yield and Composition (Cohort 2)}

No effect of L-Arg administration on milk yield (Figure 2A) was observed. Crude protein percentage was in-

\begin{tabular}{|c|c|c|c|}
\hline Measurement & $\begin{array}{c}\text { Control } \\
(\mathrm{n}=10)\end{array}$ & $\begin{array}{c}\mathrm{L}-\mathrm{Arg} \\
(\mathrm{n}=8)\end{array}$ & $P$-value \\
\hline Mammary gland weight (kg) & $1.70 \pm 0.16$ & $1.95 \pm 0.18$ & 0.35 \\
\hline \multicolumn{4}{|l|}{ Total parenchymal content (mg) } \\
\hline DNA & $0.10 \pm 0.03$ & $0.18 \pm 0.03$ & $0.07^{\mathrm{a}}$ \\
\hline RNA & $1.38 \pm 0.13$ & $1.51 \pm 0.15$ & 0.50 \\
\hline Protein & $160.11 \pm 22.27$ & $165.31 \pm 24.90$ & 0.88 \\
\hline \multicolumn{4}{|l|}{ Parenchymal concentration $(\mu \mathrm{g} / \mathrm{mg})$} \\
\hline DNA & $0.78 \pm 0.05$ & $0.81 \pm 0.05$ & 0.71 \\
\hline RNA & $0.81 \pm 0.04$ & $0.78 \pm 0.04$ & 0.58 \\
\hline Protein & $91.96 \pm 9.27$ & $88.41 \pm 10.36$ & 0.80 \\
\hline \multicolumn{4}{|l|}{ Parenchymal ratio } \\
\hline RNA:DNA & $1.03 \pm 0.03$ & $0.98 \pm 0.03$ & 0.22 \\
\hline Protein:DNA & $10.91 \pm 0.59$ & $10.33 \pm 0.66$ & 0.52 \\
\hline Protein:RNA & $10.56 \pm 0.49$ & $10.52 \pm 0.55$ & 0.96 \\
\hline
\end{tabular}

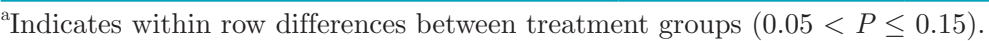




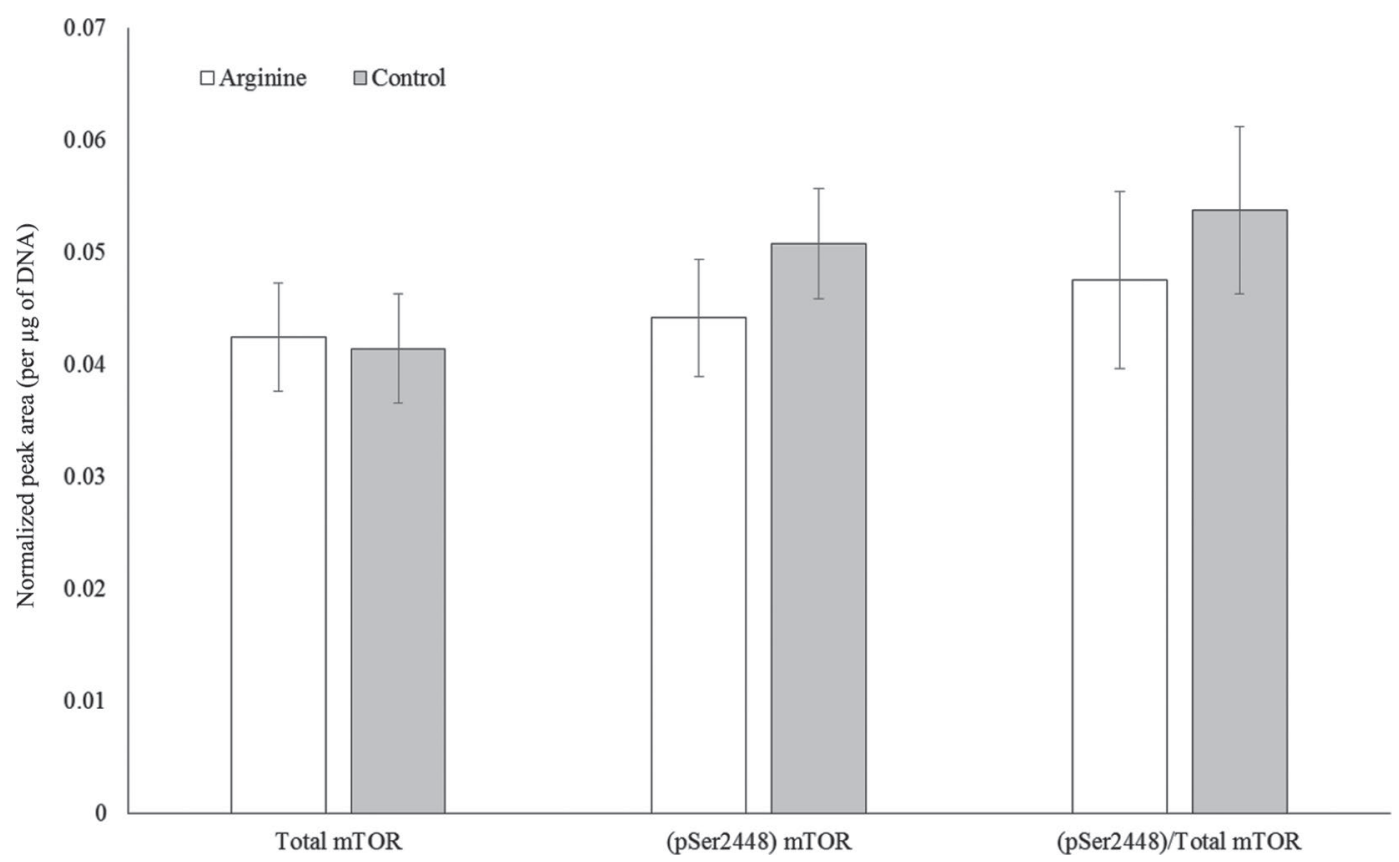

Figure 1. Total, Ser2448 phosphorylated (pSer2448), and activated (Ser2448/total) mammary mammalian target of rapamycin (mTOR) protein abundance from ewes administered L-Arg from d 100 to 140 of pregnancy. The figures shows LSM, with significance assessed as $P \leq 0.05$ and a trend as $0.05<P \leq 0.15$. Error bars denote the SEM.

creased from d 4 to 7 in L-Arg-treated ewes compared with saline-treated controls (Figure 2B). A trend for increased crude milk protein percentage was observed in saline-treated controls at d 14 compared with LArg-treated ewes (Figure 2B). We observed a trend for increased fat percentage at d 1 in saline-treated controls compared with L-Arg-treated ewes (Figure 2C). No effect of L-Arg administration on lactose percentage (Figure 2D) was observed. Milk SCC were significantly decreased $(<300,000$ cells $/ \mathrm{mL})$ from d 7 to 14 in LArg-treated ewes compared with $(>700,000$ cells $/ \mathrm{mL})$ saline-treated controls (Figure 2E).

\section{Effect of L-Arg on the Concentration of Individual FAA in Milk (Cohort 2)}

At d 7, absolute concentration of the EAA L-Tyr $(P$ $=0.05)$ and L-Phe $(P=0.06)$ were reduced (Figure $3 \mathrm{~A})$, absolute concentration of the NEAA L-Thr $(P$ $=0.14$ ) was increased (Figure $3 \mathrm{~B}$ ), and concentration of group I AA $(P=0.06)$ was reduced (Figure 3C) in L-Arg-treated ewes compared with saline-treated controls. At d 14, absolute concentration of the EAA (Figure 4A) L-Leu $(P=0.10)$, L-Tyr $(P=0.04)$, and L-Phe $(P=0.07)$ and NEAA (Figure 4B) L-Asn $(P$ $=0.14$ ) as well as concentration (Figure $4 \mathrm{C}$ ) of group I AA $(P=0.04)$ were reduced in L-Arg-treated ewes compared with saline-treated controls. No differences were observed for any of the other individual AA or AA pools analyzed at d 7 (Figure $3 \mathrm{~A}-\mathrm{C}$ ) and 14 (Figure $4 \mathrm{~A}-\mathrm{C})$.

\section{DISCUSSION}

We showed that parenteral administration of L-Arg during late pregnancy in twin-bearing Romney ewes was associated with increased total mammary gland DNA and reduced milk SCC during the first 2 wk of lactation.

Pregnancy is the most crucial time point in the growth and development of the ovine mammary gland, because, unlike many other species, ovine species have little to no cellular proliferation after parturition (Anderson, 1975). Results from this study showed that LArg-treated ewes had higher total mammary DNA, a measure of cell number and an indicator of increased lactation potential (Knight and Peaker, 1982). A potent stimulator of mammary gland development during pregnancy is insulin, which has been shown to increase cell number (Baumrucker and Stemberger, 1989; Winder et al., 1989) through the regulation of polyamine production (Rillema et al., 1977; Huber and Poulin, 1996) and cellular function via mTOR pathway stimulation (Vander Haar et al., 2007; Feuermann et al., 2008). Results from another study in the same ewes showed that L-Arg-treated ewes had elevated levels of 

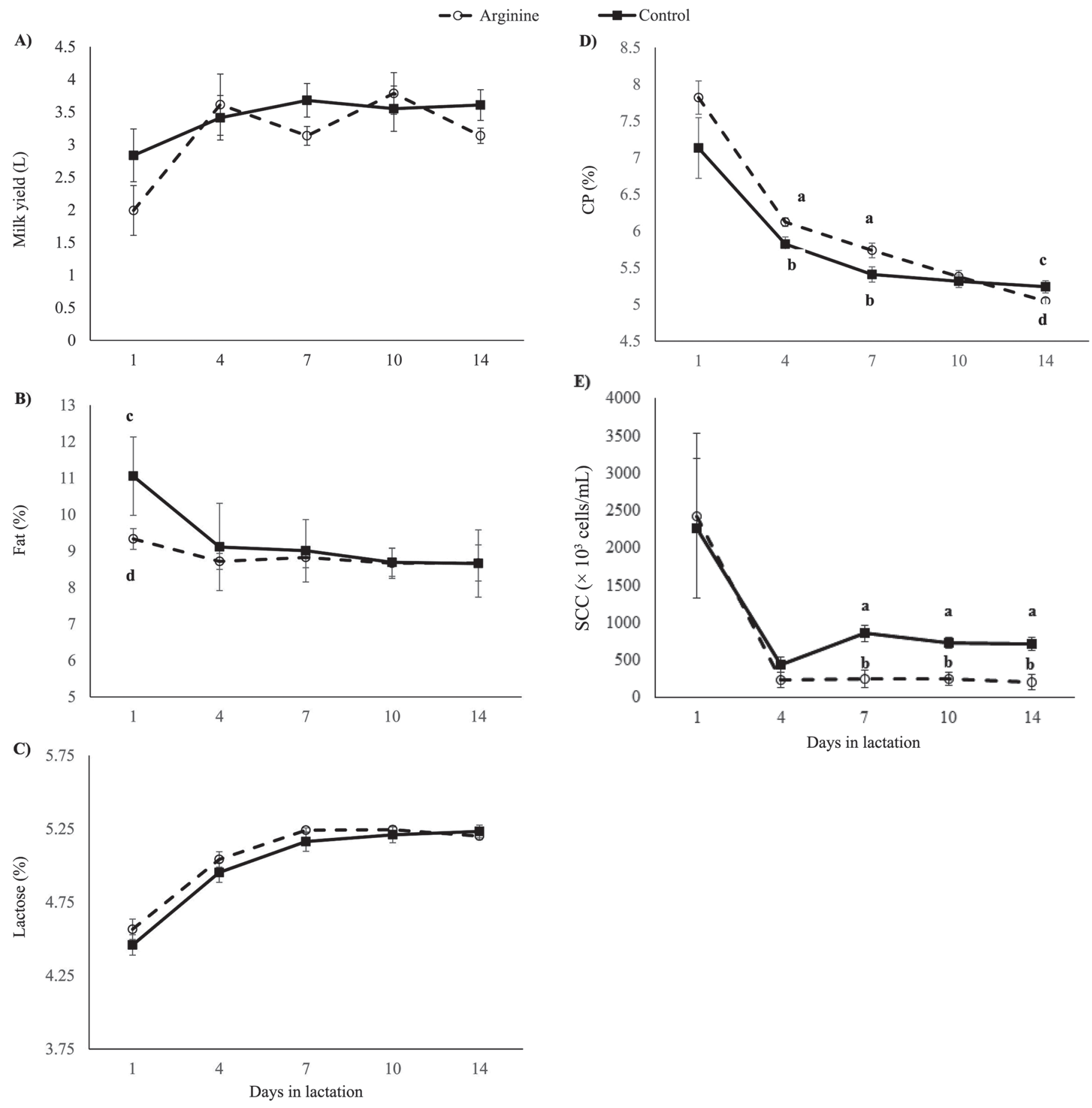

Figure 2. Milk yield (A), fat (B), lactose (C), and CP (D) percentages, and milk SCC (E) from dams administered L-Arg from d 100 of pregnancy to parturition. Data are presented as LSM \pm SEM. Means with different letters exhibit statistically significant differences $(a, b ; P \leq$ $0.05)$ or trends $(\mathrm{c}, \mathrm{d} ; 0.05<P \leq 0.15)$.

plasma insulin as well as increased L-Met and decreased L-Orn (McCoard et al., 2013), 2 AA required for polyamine synthesis (Smith et al., 1987). Whereas we found no effect on the abundance of mTOR, mTOR $^{\mathrm{Ser2448}}$, or relative activation in the mammary glands of treated ewes, it is possible that if mTOR signaling was involved activation would have occurred earlier in the treatment.

At the onset of lactation, the mammary gland is susceptible to IMI, collectively known as mastitis, which represent some of the most costly diseases in meat and 

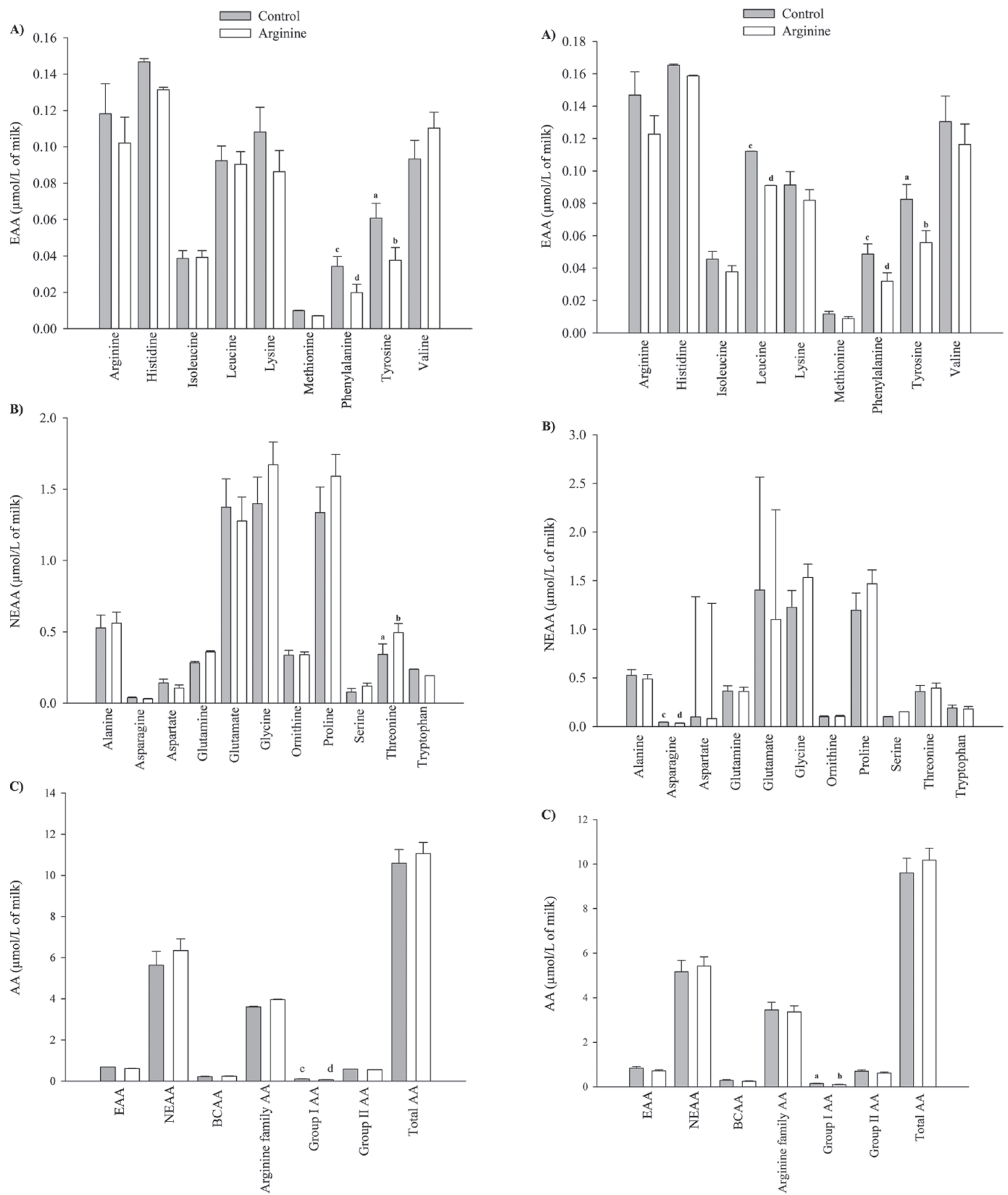

Figure 3. Individual EAA (A) and NEAA (B) and AA groups (C) at $7 \mathrm{~d}$ postpartum from dams administered L-Arg from d 100 of pregnancy to parturition. Data are presented as LSM \pm SEM. Means with different letters exhibit statistically significant differences (a,b; $P$ $\leq 0.05)$ or trends $(\mathrm{c}, \mathrm{d} ; 0.05<P \leq 0.15)$. BCAA $=$ branched-chain AA.

Figure 4. Individual EAA (A) and NEAA (B) and AA groups (C) at $14 \mathrm{~d}$ postpartum from dams administered L-Arg from d 100 of pregnancy to parturition. Data are presented as LSM \pm SEM. Means with different letters exhibit statistically significant differences (a,b; $P$ $\leq 0.05)$ or trends $(\mathrm{c}, \mathrm{d} ; 0.05<P \leq 0.15)$. BCAA $=$ branched-chain AA. 
dairy farming (Hogeveen et al., 2011). In the udder of healthy sheep, the SCC, a measure of mastitis, is low $(<500,000$ cells $/ \mathrm{mL})$, whereas the SCC can range from medium $(500,000-1,000,000$ cells $/ \mathrm{mL})$ to high $(1,000,000-2,000,000$ cells $/ \mathrm{mL})$ upon infection. In our study, the SCC for untreated ewes was between 500,000 to $1,000,000$ cells $/ \mathrm{mL}$, indicating subclinical mastitis, whereas treated ewes had SCC below 300,000, suggesting L-Arg treatment in late pregnancy improves mammary gland health. Multiple noninfectious factors can also increase SCC in sheep, with the most significant being parity, stage of lactation, season, flock, flock management, and diurnal variation (Gonzalo et al., 1994). However, noninfectious factors were discounted from contributing to the observed increase in SCC because all animals were sourced from the same flock, of similar parity, identically managed, and milked at the same stage of lactation. In addition, unlike cows and goats, sheep do not experience a postpartum surge in SCC; counts are generally stable throughout lactation (Paape et al., 2007). At the onset of mastitis, SCC provide the first line of defense (Paape et al., 2002), primarily through the production of reactive oxygen species (Boulanger et al., 2007). The production of reactive oxygen species by SCC requires L-Arg and L-Orn as substrates (Mühling et al., 2002; Bronte and Zanovello, 2005). Data from our previous study showed L-Argtreated ewes had increased levels of plasma L-Arg and L-Orn at all time points tested during the experimental period and elevated L-Orn at $2 \mathrm{~h}$ postpartum (McCoard et al., 2013).

Another indicator of mastitis is a decrease in the level of crude milk proteins (Leitner et al., 2004), which are hydrolyzed by invading bacteria to provide adequate amounts of FAA required to support bacterial survival and growth (Lincoln et al., 1995). We observed decreased CP levels at d 4 and 7 of lactation, and by d 14 they were increased in control compared with L-Argtreated ewes. The increase agrees with current studies (Le Roux et al., 2003; see Table 1) that report that, as the infection progresses, CP levels in milk can increase above uninfected levels as serum albumin proteins leak into the mammary gland through damaged tight junctions. It is worth noting that SCC have been implicated in the hydrolysis of milk proteins during mastitis and could be responsible for the observed decrease in crude milk protein percentage (Le Roux et al., 2003). In addition to reduced $\mathrm{CP}$ levels, the concentrations of milk FAA at d 7 (Phe and Tyr) and 14 (Asn, Leu, Phe, and Tyr) of lactation were higher in control compared with L-Arg-treated ewes. Although we are unaware of any studies investigating the influence of SCC number on milk FAA in sheep, 2 studies in dairy cows have been published (Csapó et al., 1995; Andrei et al., 2011).
Each study showed that SCC that were indicative of subclinical mastitis were associated with increased concentrations of all measured FAA compared with uninfected controls, but several confounding factors make extrapolation of these results to the current study difficult. Those studies did not report the lactation day samples were collected, differences exist in the bacterial species that cause mastitis in sheep and cows, and, in the current study, one group of ewes was treated with L-Arg, all of which will influence the type and concentration of FAA in milk.

We have shown that fat, lactose, and protein percentages in L-Arg-treated ewes were similar to those in Romney ewes observed in other studies, showing that administration of L-Arg had no adverse effect on milk quality or yield in the first $14 \mathrm{~d}$ of lactation (Geenty et al., 1985). Taken together, these observations suggest that L-Arg administration during late pregnancy to twin-bearing Romney ewes improves mammary gland health with no effect on milk composition. These findings have important implications for the meat and dairy industries, where high milk SCC negatively affect milk yield and quality and neonatal growth (Huntley et al., 2012).

\section{ACKNOWLEDGMENTS}

The authors acknowledge the technical expertise and support of the staff at Ngapouri Research Facility in Reporoa, New Zealand (Maggie Honeyfield-Ross, Basil Koberstein, Travis Gunn, Ana-Mishel Sproski, Anita Wylie, Keith McCallum and Anne Jaquiery). We also acknowledge funding from the AgResearch Capability Fund (Palmerston North, New Zealand), Ballance AgriNutrients (Tauranga, New Zealand), Gravida: National Centre for Growth and Development (Auckland, New Zealand), and Landcorp Farming Limited (Wellington, New Zealand). The following authors are also beneficiaries for patent number 20150313860, which was derived from this study: Quentin L. Sciascia, Danitsja S. van der Linden, and Susan A. McCoard.

\section{REFERENCES}

Akers, R. M., D. E. Bauman, A. V. Capuco, G. T. Goodman, and H. A. Tucker. 1981. Prolactin regulation of milk secretion and biochemical differentiation of mammary epithelial cells in periparturient cows. Endocrinology 109:23-30. https://doi.org/10.1210/ endo-109-1-23.

Alessi, D. R., L. R. Pearce, and J. M. Garcia-Martinez. 2009. New insights into mTOR signaling: mTORC2 and beyond. Sci. Signal. 2:pe27. https://doi.org/10.1126/scisignal.267pe27.

Anderson, R. R. 1975. Mammary gland growth in sheep. J. Anim. Sci. 41:118-123.

Andrei, S., M. Culea, S. Matei, A. Pintea, and I. S. Groza. 2011. Amino acid concentration in normal and subclinical mastitis milk. Bull. UASVM Vet. Med. 1:5.

Journal of Dairy Science Vol. 102 No. 4, 2019 
Appuhamy, J. A., N. A. Knoebel, W. A. Nayananjalie, J. Escobar, and M. D. Hanigan. 2012. Isoleucine and leucine independently regulate mTOR signaling and protein synthesis in MAC-T cells and bovine mammary tissue slices. J. Nutr. 142:484-491. https:// doi.org/10.3945/jn.111.152595.

Basch, J. J., E. D. Wickham, and H. M. Farrell. 1997. Arginase in lactating bovine mammary glands: implications in proline synthesis. J. Dairy Sci. 80:3241-3248. https://doi.org/10.3168/jds.S0022 -0302(97)76298-2.

Baumrucker, C. R., and B. H. Stemberger. 1989. Insulin and insulinlike growth factor-I stimulate DNA synthesis in bovine mammary tissue in vitro. J. Anim. Sci. 67:3503-3514.

Bolander, F. F. 1999. Regulation of prolactin receptor glycosylation and its role in receptor location. Mol. Cell. Endocrinol. 149:85-92.

Boulanger, V., L. Bouchard, X. Zhao, and P. Lacasse. 2001. Induction of nitric oxide production by bovine mammary epithelial cells and blood leukocytes. J. Dairy Sci. 84:1430-1437. https://doi.org/10 .3168/jds.S0022-0302(01)70175-0.

Boulanger, V., X. Zhao, K. Lauzon, and P. Lacasse. 2007. Effects of nitric oxide on bovine polymorphonuclear functions. Can. J. Vet. Res. 71:52-58

Bronte, V., and P. Zanovello. 2005. Regulation of immune responses by L-arginine metabolism. Nat. Rev. Immunol. 5:641-654. https:/ /doi.org/10.1038/nri1668.

Chew, B. P., J. R. Eisenman, and T. S. Tanaka. 1984. Arginine infusion stimulates prolactin, growth hormone, insulin, and subsequent lactation in pregnant dairy cows. J. Dairy Sci. 67:2507-2518. https://doi.org/10.3168/jds.S0022-0302(84)81607-0.

Clark, J. H., R. G. Derrig, C. L. Davis, and H. R. Spires. 1975. Metabolism of arginine and ornithine in the cow and rabbit mammary tissue. J. Dairy Sci. 58:1808-1813. https://doi.org/10.3168/ jds.S0022-0302(75)84791-6.

Csapó, J., Z. Csapo-Kiss, J. Stefler, T. G. Martin, and S. Nemethy. 1995. Influence of mastitis on D-amino acid content of milk. J. Dairy Sci. 78:2375-2381. https://doi.org/10.3168/jds.S0022 -0302(95)76865-5.

Davis, T. A., H. V. Nguyen, R. Garcia-Bravo, M. L. Fiorotto, E. M. Jackson, and P. J. Reeds. 1994. Amino acid composition of the milk of some mammalian species changes with stage of lactation. Br. J. Nutr. 72:845-853

Feuermann, Y., A. Shamay, and S. J. Mabjeesh. 2008. Leptin upregulates the lactogenic effect of prolactin in the bovine mammary gland in vitro. J. Dairy Sci. 91:4183-4189. https://doi.org/ 10.3168/jds.2008-0988.

Geenty, K. G., J. N. Clarke, and D. E. Wright. 1985. Lactation performance, growth, and carcass composition of sheep. 2. Relationships between ewe milk-production, lamb water turnover, and lamb growth in romney, dorset, and crossbred sheep. N. Z. J. Agric. Res. (Lahore) 28:249-255. https://doi.org/10.1080/00288233.1985 .10420935 .

Gonzalo, C., J. A. Carriedo, J. D. Gomez, L. D. Gomez, and F. San Primitivo. 1994. Diurnal variation in the somatic cell count of ewe milk. J. Dairy Sci. 77:1856-1859. https://doi.org/10.3168/jds S0022-0302(94)77127-7.

Hogeveen, H., K. Huijps, and T. J. Lam. 2011. Economic aspects of mastitis: New developments. N. Z. Vet. J. 59:16-23. https://doi .org/10.1080/00480169.2011.547165.

Huber, M., and R. Poulin. 1996. Permissive role of polyamines in the cooperative action of estrogens and insulin or insulin-like growth factor I on human breast cancer cell growth. J. Clin. Endocrinol. Metab. 81:113-123. https://doi.org/10.1210/jcem.81.1.8550737.

Huntley, S. J., S. Cooper, A. J. Bradley, and L. E. Green. 2012. A cohort study of the associations between udder conformation, milk somatic cell count, and lamb weight in suckler ewes. J. Dairy Sci. 95:5001-5010. https://doi.org/10.3168/jds.2012-5369.

Kim, J. Y., R. C. Burghardt, G. Wu, G. A. Johnson, T. E. Spencer, and F. W. Bazer. 2011. Select nutrients in the ovine uterine lumen. VIII. Arginine stimulates proliferation of ovine trophectoderm cells through MTOR-RPS6K-RPS6 signaling cascade and synthesis of nitric oxide and polyamines. Biol. Reprod. 84:70-78. https://doi.org/10.1095/biolreprod.110.085753.
Kim, S. W., and G. Wu. 2009. Regulatory role for amino acids in mammary gland growth and milk synthesis. Amino Acids 37:8995. https://doi.org/10.1007/s00726-008-0151-5.

Knight, C. H., and M. Peaker. 1982. Development of the mammary gland. J. Reprod. Fertil. 65:521-536.

Laplante, M., and D. M. Sabatini. 2012. mTOR Signaling. Cold Spring Harb. Perspect. Biol. 4. https://doi.org/10.1101/cshperspect .a011593.

Lassala, A., F. W. Bazer, T. A. Cudd, S. Datta, D. H. Keisler, M. C. Satterfield, T. E. Spencer, and G. Wu. 2011. Parenteral administration of L-arginine enhances fetal survival and growth in sheep carrying multiple fetuses. J. Nutr. 141:849-855. https://doi.org/10 $.3945 /$ jn.111.138172.

Le Roux, Y., F. Laurent, and F. Moussaoui. 2003. Polymorphonuclear proteolytic activity and milk composition change. Vet. Res. 34:629-645. https://doi.org/10.1051/vetres:2003021.

Leitner, G., M. Chaffer, A. Shamay, F. Shapiro, U. Merin, E. Ezra, A. Saran, and N. Silanikove. 2004. Changes in milk composition as affected by subclinical mastitis in sheep. J. Dairy Sci. 87:46-52.

Lincoln, R. A., J. A. Leigh, and N. C. Jones. 1995. The amino acid requirements of Staphylococcus aureus isolated from cases of bovine mastitis. Vet. Microbiol. 45:275-279.

McCoard, S., F. Sales, N. Wards, Q. Sciascia, M. Oliver, J. Koolaard, and D. van der Linden. 2013. Parenteral administration of twinbearing ewes with L-arginine enhances the birth weight and brown fat stores in sheep. Springerplus 2:684. https://doi.org/10.1186/ 2193-1801-2-684.

Mepham, T. B. 1982. Amino acid utilization by lactating mammary gland. J. Dairy Sci. 65:287-298. https://doi.org/10.3168/jds.S0022 $-0302(82) 82191-7$

Mühling, J., M. Fuchs, C. Fleck, A. Sablotzki, M. Krull, M. G. Dehne, J. Gonter, S. Weiss, J. Engel, and G. Hempelmann. 2002. Effects of arginine, L-alanyl-L-glutamine or taurine on neutrophil (PMN) free amino acid profiles and immune functions in vitro. Amino Acids 22:39-53. https://doi.org/10.1007/s726-002-8200-9.

Nader, G. A., T. J. McLoughlin, and K. A. Esser. 2005. mTOR function in skeletal muscle hypertrophy: Increased ribosomal RNA via cell cycle regulators. Am. J. Physiol. Cell Physiol. 289:C1457C1465. https://doi.org/10.1152/ajpcell.00165.2005.

National Research Council. 1985. Nutrient Requirements of Sheep. 6th rev. ed. Natl. Acad. Press, Washington, DC.

Nicklin, P., P. Bergman, B. Zhang, E. Triantafellow, H. Wang, B. Nyfeler, H. Yang, M. Hild, C. Kung, C. Wilson, V. E. Myer, J. P. MacKeigan, J. A. Porter, Y. K. Wang, L. C. Cantley, P. M. Finan, and L. O. Murphy. 2009. Bidirectional transport of amino acids regulates mTOR and autophagy. Cell 136:521-534. https:// doi.org/10.1016/j.cell.2008.11.044.

Paape, M., J. Mehrzad, X. Zhao, J. Detilleux, and C. Burvenich. 2002. Defense of the bovine mammary gland by polymorphonuclear neutrophil leukocytes. J. Mammary Gland Biol. Neoplasia 7:109-121.

Paape, M. J., G. R. Wiggans, D. D. Bannerman, D. L. Thomas, A. H Sanders, A. Contreras, P. Moroni, and R. H. Miller. 2007. Monitoring goat and sheep milk somatic cell counts. Small Rumin. Res 68:114-125. https://doi.org/10.1016/j.smallrumres.2006.09.014.

Pau, M. Y., and J. A. Milner. 1982. Effect of arginine deficiency on mammary gland development in the rat. J. Nutr. 112:1827-1833. https://doi.org/10.1093/jn/112.10.1827.

Ploszaj, T., T. Motyl, W. Zimowska, J. Skierski, and L. Zwierzchowski. 2000. Inhibition of ornithine decarboxylase by alpha-difluoromethylornithine induces apoptosis of HC11 mouse mammary epithelial cells. Amino Acids 19:483-496.

Rillema, J. A., B. E. Linebaugh, and J. A. Mulder. 1977. Regulation of casein synthesis by polyamines in mammary gland explants of mice. Endocrinology 100:529-536. https://doi.org/10.1210/endo $-100-2-529$.

Robinson, J. J., I. McDonald, I. McHattie, and K. Pennie. 2009. Studies on reproduction in prolific ewes. 4. Sequential changes in the maternal body during pregnancy. J. Agric. Sci. 91:291-304. https: //doi.org/10.1017/s0021859600046372.

Sciascia, Q., D. Pacheco, and S. A. McCoard. 2013. Increased milk protein synthesis in response to exogenous growth hormone is as- 
sociated with changes in mechanistic (mammalian) target of rapamycin (mTOR)C1-dependent and independent cell signaling. J. Dairy Sci. 96:2327-2338. https://doi.org/10.3168/jds.2012-6267.

Sciascia, Q. L., D. Pacheco, and S. A. McCoard. 2015. Administration of exogenous growth hormone is associated with changes in plasma and intracellular mammary amino acid profiles and abundance of the mammary gland amino acid transporter SLC3A2 in midlactation dairy cows. PLoS One 10:e0134323. https://doi.org/10 .1371/journal.pone.0134323.

Smith, T. K., T. Hyvonen, R. L. Pajula, and T. O. Eloranta. 1987. Effect of dietary methionine, arginine and ornithine on the metabolism and accumulation of polyamines, S-adenosylmethionine and macromolecules in rat liver and skeletal muscle. Ann. Nutr. Metab. 31:133-145. https://doi.org/10.1159/000177260.

Sobolewska, A., M. Gajewska, J. Zarzynska, B. Gajkowska, and T. Motyl. 2009. IGF-I, EGF, and sex steroids regulate autophagy in bovine mammary epithelial cells via the mTOR pathway. Eur. J. Cell Biol. 88:117-130. https://doi.org/10.1016/j.ejcb.2008.09.004. van der Linden, D. S., P. R. Kenyon, H. T. Blair, N. Lopez-Villalobos, C. M. Jenkinson, S. W. Peterson, and D. D. Mackenzie. 2009 Effects of ewe size and nutrition on fetal mammary gland development and lactational performance of offspring at their first lactation. J. Anim. Sci. 87:3944-3954. https://doi.org/10.2527/jas.2009 $-2125$.

Vander Haar, E., S. I. Lee, S. Bandhakavi, T. J. Griffin, and D. H. Kim. 2007. Insulin signalling to mTOR mediated by the Akt/PKB substrate PRAS40. Nat. Cell Biol. 9:316-323. https://doi.org/10 $.1038 /$ ncb1547.

Winder, S. J., A. Turvey, and I. A. Forsyth. 1989. Stimulation of DNA synthesis in cultures of ovine mammary epithelial cells by insulin and insulin-like growth factors. J. Endocrinol. 123:319-326.

Yao, K., Y. L. Yin, W. Chu, Z. Liu, D. Deng, T. Li, R. Huang, J. Zhang, B. Tan, W. Wang, and G. Wu. 2008. Dietary arginine supplementation increases mTOR signaling activity in skeletal muscle of neonatal pigs. J. Nutr. 138:867-872. https://doi.org/10 $.1093 /$ jn/138.5.867. 